Article

\title{
The Role of Military Service in the Integration/Segregation of Muslims, Christians and Druze within Israel
}

\author{
Rami Zeedan 1 \\ Jewish Studies Program, The University of Kansas, Lawrence, KS 66045, USA; Rzeedan@ku.edu
}

Received: 19 October 2018; Accepted: 28 December 2018; Published: 8 January 2019

\begin{abstract}
This study applies the negative peace/positive peace approach to internal nation-state relations between the majority and ethnic minority. This approach focuses on the policies implemented by the state. In order to understand the social system from its formation, an important focus should be given to the period of establishment of a new state, whereas physical borders are defined along with the borders of society, which determines who is included in the new nation and who is excluded. The conclusions are based on the case of the Israeli Druze, an ethnic minority with whom the state of Israel and its Jewish majority have achieved positive peace. This study suggests that the positive peace with the Druze was achieved following their integration in the army-as a decision of the state of Israel-that lead to their integration in the Israeli society. Conversely to the Israeli Muslims, where a negative peace is maintained, following the early year's state policy to exclude them.
\end{abstract}

Keywords: Israel; positive peace; druze; compulsory service; social integration

\section{Introduction}

Current 'peace research' focuses on negative peace and positive peace [1], where negative peace involves the reduction, prevention or absence of war and violence, while positive peace involves a sense of cooperation or integration. Galtung [2] first defined positive peace as 'the integration of human society' and later [3] redefined it as the negation of 'structural violence.' In other words, positive peace emanates from the structure of a social system rather than from individual or group actors. "Structural violence" is a form of violence in which some social structure or social institution may prevent people from meeting their basic needs. It voices the hidden violence built into the structure of society itself, not specific individuals, and appears as the violence of injustice and inequity [4]. Such structures include social relations and arrangements (i.e., economic, political, legal, religious, or cultural) and may be reflected in many forms, such as by race, ethnicity, gender, sexual orientation and migrant or refugee status [5].

In the early 1980s, a somewhat similar discussion arose regarding the proper definition of 'security'. The Palme Commission [6] formulated the concept of 'common security', which focused on a multidimensional perspective in which nondefense elements of security are given significance. Later, other scholars such as Westing [7] began referring to 'comprehensive security', which included 'environmental security' as an important component. The Copenhagen School of International Relations expanded the concept of security to include military, political, societal, economic, and environmental dimensions [8]. In 1994, the Human Development Report promoted the term 'human security' [9], which encompassed economically, food, health, environmental, personal, community and political security. This broad conception of security was meant to accommodate those who felt that a traditional state-based security concept, which aimed solely to protect national territory, was overly narrow. 
Concurrently, critics argued that the concept of human security, similar to the idea of structural violence, was excessively broad. Thus, the Human Security Report, while retaining an emphasis on the protection of individuals, settled for a narrower definition of human security focused on 'violent threats to individuals' [10]. The 'sustainable security' approach prioritizes resolution of the interconnected underlying drivers of insecurity and conflict, with an emphasis on preventive strategies as opposed to reactive [11]. Current approaches to global security are characterized by the 'control paradigm,' an approach based on the premise that insecurity can be controlled through military force or containment with the goal of maintaining the status quo. The central premise of the sustainable security approach is that we cannot successfully manage all the consequences of insecurity (such as terrorism, crime or extreme leadership) and that we must work to resolve its causes. In other words, fighting the symptoms will not work; instead, it is necessary to focus on curing the disease. Sustainable security requires an understanding of the three interlinked pillars of society, economy, and environment, which are central issues for sustainable development [12].

Therefore, exploring issues regarding the security of a specific state or nation necessarily involves acquiring an understanding of its social, economic, and environmental systems. This approach is more complicated in multicultural nations or nation-states that include an ethnic minority than in heterogeneous states. In such cases, ethnic majority—minority relations often lead to violent conflicts and unsustainable security or negative peace. The social, economic, and environmental systems of any country may be altered by certain internal or external factors; however, in multicultural nations and nation-states, the sole basis of the social order is sometimes defined in the early period of the new state's establishment as the new entity defines its borders. It includes defining not only land borders-determining both where state sovereignty and administration begins and ends and which territories included-but also the limits of society, i.e., who is included in the new nation and who is excluded. Any later attempts to redefine these borders will almost certainly involve ethnic cleansing, which has mostly been criticized by most nations and societies in the 21st century. Therefore, our focus in this study is the understanding of the social integration of ethnic minority/minorities within a nation-state and its relation to positive/negative peace.

Ethnic minorities in nation-states live on the margins of society by definition. Throughout history, the response of the majority towards the minority has ranged from elimination or expulsion to integration or assimilation. Common problems involve the majority withholding collective or individual rights from the minority or the outbreak of any level of ethnic tension-from either side - that leads to ethnic-based violence, as in southern Kyrgyzstan in 2010, or even massacres or genocide, such as those in Bosnia in the 1990s. Yet, in some rare cases, nation-states accept specific minorities as part of the nation; for example, Germany granted the Sorbs cultural rights in the 19th century. In other models, ethnic minorities are integrated or assimilated into the majority. Furthermore, some minorities seek appropriate ways of becoming integrated, whereas others pursue territorial autonomy or secession. The likelihood of the violent rebellion of minorities is influenced by the level of power that the minority has vis-à-vis the majority, ethnic fears and political discrimination [13].

In light of the preceding, our primary focus in this study is to investigate the consequences of the process of establishing a new multicultural nation on the sustainable security of a state. Our primary goal is to examine and identify the policies a nation-state implements to achieve positive peace with an ethnic minority.

Our case study focuses on Israel, which was created in 1948 as the national home of the Jewish people [14]. However, since its establishment, the Israeli population has included an Arab minority. Arabs in Israel consider themselves as indigenous people of Palestine who are under the rule of a majority that is mainly nonindigenous [15]. According to international declarations and treaties [16], indigenous people are those who have historically lived in a specific place and who are different from the majority regarding ethnicity, language and nationality. This perspective on indigenous people has strengthened the self-awareness and national demands of the Arab minority. Since 1948, these 
demands and self-awareness have also been influenced externally by the Arab-Israeli conflict (as the Arab minority is part of both the larger Arab society in the region and also part of the Palestinian people). Moreover, it was influenced by internal aspects, such as the attitude of the Israeli state towards its Arab citizens, which involves discrimination in budgetary allocations and a lack of equality regarding both individual and collective rights.

The Arab-Palestinians living within the Green Line in Israel form a society that constituted approximately $20 \%$ of the Israeli population as of 2015. Arab society is composed of roughly $80 \%$ Sunni-Muslims, 10\% Christians (affiliated with several sects, such as Greek-Catholic and Greek-Orthodox), and 8\% Druze. Their self-identification, which has changed over time, has recently been the subject of extensive study [15,17-20]. Currently, most of the Arabs in Israel identify themselves mainly as Arab-Palestinians; however, they have other dimensions of identity: civic identity as Israelis; religious identity as Muslims, Christians, or Druze; and regional identities [20].

This self-identification has created a contradiction between this group's Israeli civic identity and its Arab-Palestinian national identity. This contradiction has had a significant influence on the group's political behavior for three significant reasons: the renewal of Arab Israelis' connections with the Palestinian population in the West Bank and Gaza after the 1967 war; the cancellation of the military administration of Arab-populated areas in 1966 that allowed the freedom of movement and more freedom of expression; and the rise of the Palestinian national movement in the 1960s.

Recently, it was suggested that the vast majority of the Arab minority in Israel wants to coexist with Jews in Israel, want to remain citizens of Israel, and overwhelmingly prefer peaceful protest over violence to achieve change [21-23]. However, it is worth mentioning the developments over Israel's history. Until the 1970s, Israeli-Arabs' political violence was conduct by individuals and was presumed as protests against the existence of the state [24]. Since the late 1970s, an escalation is notices in the Israeli-Arabs' political violence towards the state of Israel and its Jewish majority. Violence at the national level occurred on several occasions, among the most critical events of them are: the first Land Day in March 1976; protests during the first Intifada (1987-1991); the October 2000 clashes; protests during the second Intifada (2000-2007); and recently in 2015, violence erupted mainly in Jerusalem due to tensions over the status of the Temple Mount/the Noble Sanctuary [24].

Not all parts of Arab society have been involved in the ongoing tension. Most of the Druze community in Israel did not participate in the violent events mentioned above. Previous scholarship suggested multiple explanations for such political violence such as biological, psychological, cultural, social, religious-based intolerance, and political issues. A study focusing on Israel found that support of political violence was most influenced by deprivation, regardless of ethnicity, religion, or level of religiosity [24]. However, socioeconomic gaps cannot explain the difference between the Druze and other Arabs in Israel, just because there is not much difference in the inequality of the Druze compared to Muslims or Christians [25].

For that, the explanation is not found in the religious difference between the Druze and other Arabs or in socioeconomic gaps. Instead, it may be a result of the differentiated self-identification and political patterns of the Druze. Recently, Halabi [17] found that in contrast to other Arabs in Israel, religious self-identification was seen to be dominant among the Druze, followed by their Israeli and Arab identities, with some differences between interviewees. Halabi [17] found that most of the Druze interviewees did not have a Palestinian identity as one of their self-identification dimensions.

Religious affiliation and identity are not the only characteristics that distinguish the Druze from other Arabs in Israel, Muslims and Christians alike. Their political trends have been different for decades: in recent years, the majority of Druze have voted in national elections for Zionist parties rather than Arab parties (81\% of the Druze vote for Zionist parties compared with 19\% of other Arabs) conversely to Muslims and Christians who are voting mainly to Arab parties. In local politics, the Druze mayors of Druze municipalities are not part of the National Committee of Arab Mayors (established 1974); instead, they formed a separate Committee of Druze and Circassian Mayors [26] in 1979. As a result, when the National Committee of Arab Mayors established the High Follow-Up 
Committee for Arab Citizens of Israel-nowadays the most important political institution representing Arab issues in Israel-the Druze leadership was not part of it, and still is not part of it. Moreover, in three branches of power in Israel, there are more elected or appointed Druze citizens than Muslims or Christians, except for the judiciary. In the Knesset, the Druze have been overrepresented in the past two decades due to their integration in Zionist parties from the left wing to the right. A Druze Member of the Knesset (from now on-MK) was the first non-Jewish to serve as a minister in 2001 as part of any Israeli government. Since 2001, the Arab MKs who were appointed as part of any Israeli government-as ministers or deputy ministers-were all Druze, except one. At the same time, an elevation was noticed in promotions of Druze officers in the IDF to higher ranks in a move to integrate them equally in the army [27]. Such as a Druze officer that was promoted in 2001 for the first time to the rank of major general - the second highest rank after the chief of staff of the IDF and part of the IDF general staff. A second Druze to be appointed to an IDF position at the rank of major general was followed in 2018. These actions are to reflect the perspective of significant parts of the Israeli society that considers the Druze as part of the Israeli consensus, in contrast to the other Arabs.

All these characteristics of segregation of the Druze community from the Arab political discourse should be seen as a reflection of the Druze considering themselves more and more an integral part of Israeli society, compared to the other Israeli Arabs [17]. Consequently, ethnic-based violence between the Druze and the state or with other Jewish citizens in Israel is rare. The riots that have occurred-such as the Druze's long series of protests over economic discrimination against their localities in 1994 [28], the conflict over a cellular phone antenna in Buqaya'a in 2007 [29], or the dispute in 2008-2010 over the expropriation of the Druze's lands in Mount Carmel-have been fully Druze-motivated with no Palestinian-nationalistic characteristics and thus in general generate sympathy among Israeli Jews and the Hebrew media. The sympathy for these Druze causes contrasts with the lack of sympathy for other Arab protests and violent incidents. There are some exceptions, such as "The Arab-Druze Initiative Committee" and "The Free Sons of Grace" who reject the separation of Druze from Palestinian nationalism and fight against the conscription of the Druze youth in the IDF. However, both initiatives were not successful in attracting much support among Israeli Druze.

Thus, this study suggests that there is a positive peace between the Israeli Druze-as an ethnic minority - and the Jewish majority in the nation-state of Israel, which stands in stark contrast to the circumstances of other Arabs residing within Israel. By doing so, we apply the negative peace/positive peace approach to internal nation-state relations between the majority and ethnic minority. We want to examine how the negation of structural violence was achieved with the Druze. Hence our focus tends to investigate the period of establishment of a new state, whereas the borders of society are defined. As such, the research is focused on proper-Israel, i.e. within the Green-Line.

Consequently, this research investigates how a positive peace has been achieved with the Druze and explores the factors that resulted in this contrast with other Arab-Muslims and Arab-Christians. To achieve our goal of identifying the policies that a nation-state implements to achieve positive peace with an ethnic minority, we must answer the following questions: Has this positive peace been in place since 1948? Has the Druze's political behavior differ concerning other topics? What are the sources of such different political behaviors among the Druze? Are these differences a product of governmental policies? Can such policies be duplicated?

\section{Materials and Methods}

To answer these questions, an examination of Israeli policies was conducted, with a particular focus on those implemented in the early period of Israel's statehood, using documents obtained mainly from official Israeli archives, mainly the Israel Defense Forces Archives (IDFA) and the Israel State Archives (ISA). The archival research was an intensive and systematic search that included all open and available documents on the topic in those archives from all relevant units and departments. Relevant documents were found by searching for the relevant years (until the early 1960s) and relevant words in the titles of those files-i.e., Arab, Druze, Muslim, Christian, Circassian, Minorities, non-Jewish, 
compulsory service. Furthermore, the search included files from relevant government departments and ministries-i.e., Minorities ministry/advisor, Prime Minister office, Ministry of Defense, Ministry of foreign affairs - and IDF units—i.e., Minorities Unit, 300 Unit, 299 Unit/Battalion, 244 Unit, irregular squads, Chief of Staff, Human Resources branch, Northern Command, Northern Command, Central Command, Intelegance Command, Operations Command. By the end of the search, a few thousands of documents were examined coming from hundreds of files.

After careful review, the relevant documents were saved or copied and then were examined through content analysis and compared to the current historiography [30]. In cases where the new materials re- $\backslash$ confirmed the known policies and decisions as mentioned in already published scholarly work, this was explained in the text as such and citation to the new primary sources was added. However, in a few cases, a document or a series of documents showed a different pattern of policies than previously known and published on the issue. Those cases were further examined, by adding more materials to support the claim and find consistency. Furthermore, those documents were compared to additional documents from different files, from different units and departments, and various archives- all to make sure that the new finding based on facts. This was also done with cases of policies that have been discovered and published by other scholars but was based only on interviews. The novelty in this manuscript is based in part on those new findings, which contradict with what was known.

All documents that this research is based on, were analyzed critically, by examining the assumptions behind each document and by examining other aspects that may have been omitted from it. While examining those documents, we asked: Why the record was created? What it says (explicitly or implicitly)? And, what is not mentioned? Using the answers to these question, it was possible to identify the facts, the connection between them, and their chronological and thematic context. Furthermore, any gaps were identified and referred to in the manuscript as such. As part of the examination, few documents were found as miss-leading or falsely. Those were treated as such, and the text in this manuscript refers to them accordingly.

\section{Results}

\subsection{The "Divide and Conquer" Policy}

At the outset, we must answer the first question: Has this positive peace been in place since 1948? In brief, the answer is no: this has not been the case since Israel was established. Instead, this positive peace was a product of a process involving several governmental decisions with one main characteristic - integrating the Druze and segregating others.

Beginning with its establishment as a nation-state until the mid-1960s, Israel focused on designing and implementing policies in various areas: foreign policy, which was based on its relationship with the Arab world; societal and economical interior policy; and identity, which focused on strengthening the Jewish-Zionist character of the state. Within these three areas, there was a particular element of consideration for Arab society: in foreign policy, Arab Israelis were considered part of the Arab world and therefore an enemy of Israel; thus, they were perceived as a threat to national security. Based on this perspective, Israel established a military government regime in Arab-populated areas that lasted until 1967. Regarding internal policy, the remaining Arabs in Israeli territories were accepted as permanent residents and citizens, except Arab refugees who escaped during the war and later attempted to return to their homes. However, Arabs were not part of the Israeli collective and were excluded from the melting pot—-the ingathering of exiles—of the new society. Consequently, Arabs remained at the margins of Israeli society, a position that they have been unable to change since that time, even after Israel abolished military administration of Arab areas. Regarding the Jewish-Zionist identity of the state, the attitude towards Arabs was based solely on security motives, which involved keeping Arabs under strict supervision to prevent them from interfering in the processes of building 
the new state- the army, the economy, Jewish settlements, and the integration of new immigrants—and in the design of Israel's characteristics as the state of the Jewish people.

Subsequently, and to maintain effective control over the Arabs within Israel, Arab society was not treated as a single united society to prevent its development into a robust national minority [31]. A 'divide and conquer' policy was implemented by Israel [32] in which non-Jewish minorities were divided into groups of religious/social affiliations-Muslims, Christians, Druze, Bedouins, and Circassians-as if they lacked common features.

This policy was manifest in formal government and agency documents and even in academic publications, as demonstrated in the following examples. In 1956, the Census of Population and Housing [33] divided the population into Jews and non-Jews; there were no other sub-categories. Later, in a special census of the newly occupied territories [34], the population was divided based on religion: Muslims, Christians, and others. Subsequently, a method was developed to categorize minorities based on their religions: Muslims, with internal sub-divisions; Christians, with internal sub-divisions; and Druze [35]. A more detailed academic study [36] that focused on the minorities in Israel categorized the minorities into religious divisions with multiple sub-divisions.

The 'divide and conquer' policy of categorization was not restricted to publications; it became official through a process that began in 1957 and led to the official recognition of the Druze religion in Israel. A plan to "ethnicize" the Druze was carried out over the years [22] by implementing political, economic, and educational policies [29], as will be explained further in the following historical review.

\subsection{Integrating the Druze, Segregating Others}

The Druze have been a minority in the Middle East since the establishment of the Druze religion in the 11th century in Egypt under the Fatimid Caliph al-Hakim bi-Amr Allah. Following his disappearance in 1021, the Druze religion lost its state endorsement, which led to them being persecuted and forcing them to seek refuge in small and closed communities [37]. At that time, Muslim leaders considered the Druze traitors to Islam. Thus, most of the Druze hid their beliefs by following the Taqiyah tradition (precautionary dissimulation) in order to survive.

During the Ottoman period, the Druze in the Middle East were recognized as part of Muslim society. Some of the requests made by Druze leaders to be known as a separate millet, or people, were not approved by the Ottoman administration [38]. Recognition as millet by the Ottoman millet system would have granted the Druze the protection of the central government and allowed the Druze community to rule itself under its legislative system - providing them with a form of religious autonomy and self-management. The Druze did not typically appear by name in official government documents and statistics; instead, they were referred to as "Muslims" or "others" [39]. Renewed and repeated requests by some Druze leaders to recognize their community as a separate millet during the British Mandate over Palestine [40] were rejected.

Following the formation of the state of Israel, the millet system was reapproved as an Israeli law with some minor changes. Judaism, nine churches of Christianity, and Islam were all approved as recognized religions [41]. Following renewed official requests from Druze leaders, the Israeli government agreed to expand the recognized religions by adding Druze in 1957 [42]. The Druze were officially recognized as an autonomous religious community in 1962 [43] when the Knesset approved the Druze Religious Courts Act (1962), which was followed by appointing an official Druze spiritual leadership and Druze religious judges.

Furthermore, Israel granted the Druze religious leadership control over religious property, allowing the Druze to control their Waqf properties while withholding such authority from the Muslim spiritual leaders. A similar action was taken in the 1950s when control over their religious properties was returned to the Greek-Catholic church [44]. This action, along with others, was implemented as part of an effort to encourage the so-called 'positive' forces among the Druze [45].

Following this recognition, the Ministry of the Interior made this distinction clear on Israel identity cards and birth certificates. These official documents also indicated the nationality and religion of 
every citizen [46], whether it was Jewish, Christian or Arab/Muslim. In 1962, the Ministry of the Interior added the Druze nationality/religion- without distinction between the two- to this list by replacing the term 'Arab' with 'Druze' for every Israeli Druze. This led to an official Israeli stance that claimed that the Druze were no longer Arabs [47], thus completing the plan to invent a specific identity for the Israeli Druze.

In 1970, Prime Minister Levi Eshkol resolved to disassociate the Druze from the Arab/Minority affairs sections of the government, which enabled the Druze to access appropriate departments of the government directly [48]. This decision was first made for the Druze and was later extended to include other Arabs. The same pattern was implemented when the Labor party, followed by the Likud and other Zionist parties, accepted the Druze as equal party members in the early 1970s [49]. However, Muslims and Christians were allowed to be affiliated only with Arab parties for several more years before they were granted the same level of acceptance as the Druze [48]. Later in 1976, to cope with the possible radicalization of the Druze community following the first Land Day in March 1976 and with growing opposition to compulsory service for Druze youth-amid the formation of the Druze Initiative Committee in March 1972-the Israeli Ministry of Education separated Druze schools from the Arab education system and established a separate Druze education system [42]. The intent was to create an Israeli-Druze consciousness among the students, as cited by Halabi [17], by creating a curriculum that covered the Druze religion, culture, and history.

However, the primary tool to distinguish among parts of Arab society was service in the army, which was introduced through the establishment of the Minorities Unit in the Israel Defense Forces (IDF) in 1948 [50]. All the Israeli actions mentioned above to distinguish the Druze from other Arabs occurred after the implementation of compulsory service for Druze youth in 1956. Notably, this is also linked to the reason for establishing the Committee for Druze and Circassian Mayors and the Druze and Circassian education system, as the only common characteristic between those two minority groups was their compulsory service in the IDF.

Moreover, according to several recent studies, there is no doubt that the Druze in Israel identify as Israeli more than other Arabs and that conscription in the army is the factor that has had the most significant impact on the Druze identity in Israel [17]. Consequently, this study suggests that conscription in the army was the turning point regarding Druze identity.

The sources of the policy to integrate the Druze while segregating others are connected to service in the IDF. Compulsory service for Druze youth, similar to mandatory service for Jewish youth, has led to greater integration of the Druze in Israeli society and thus to a positive peace through the implementation of the policies discussed above. Simultaneously, excluding other Arabs from army service has led to a negative peace between the Arab ethnic minority and the nation-state. Therefore, it is essential to now answer our other questions: What are the sources of such different political behaviors among the Druze? Are these differences a product of governmental policies? We can add to these: If so, how were these policies implemented differently for Muslims, Christians, and the Druze?

\subsection{The Compulsory Service of the Druze in the IDF}

The civil- and security-based connections between Arabs and Zionist Jews in Palestine originated with the beginning of the Zionist presence in Palestine in the late 19th century [31]. However, a significant change occurred before and during the 1948 War [51]. Arab troops were integrated with Jewish forces in some of the infantry brigades in the first half of 1948, even before the official establishment of Israel and the IDF [50]. These troops included volunteers-mainly mercenary soldiers-of different backgrounds, such as Muslim-Bedouin, Muslim-Circassian, Druze and Christian. An IDF Minorities Unit was established in August 1948 to consolidate all the minority units that had already been formed by local army commanders rather than by the central command [52]. This Minorities Unit was established under the control of Lieutenant Colonel Tovia Lishanskey from the Intelligence Corps. Through a process that continued until 1956, the Minorities Unit became a de facto Druze unit [50]. 
The Israeli government debated the service of Arabs in the army from its earliest days as a nation-state but did not establish a clear and consistent policy. Following Ben-Gurion's decision, the first Defense Service Law (1949) established compulsory service only for Jews and granted the Defense Minister the ability to exempt individuals or groups from mandatory service for religious and national reasons; Arab citizens were among those exempted groups. Over the years, hundreds of Arab applicants have asked to register [50]. Most were denied, presumably following Ben-Gurion's policy of supporting a mandatory draft for minorities and Jews that distinguished between trustworthy minorities, i.e., Druze and Circassians, and potentially suspect minorities, i.e., Muslims and Christians [53]. From 1948 to 1953, under Prime Minister and Defense Minister Ben-Gurion, Arabs were excluded from central state institutions that were responsible for fulfilling the task of creating Israeli Jewish citizens, including the army [54].

This policy changed during Pinhas Lavon's brief tenure as Defense Minister (1954-1955). Lavon suggested compulsory service for all the Arabs to equalize rights and obligations, as claimed in an official press note [54]. Arab male youth between the age of 18 and 20 were asked to register for military service in July 1954 . This was an unexpected outstanding success. More than $90 \%$ of eligible youth registered (4000 of 4520 by October 1954) within a few months [54] despite the opposition of their families, which was due mainly to economic circumstances, cultural assimilation, and the Arab-Israeli conflict.

However, during the registration process, Lavon had some doubts about the process and its consequences. Meetings of the IDF and the Defense Minister on this topic were held between July and September 1954. In those meetings, Lavon decided to implement the process in three stages to better use the state's human resources in case of an emergency [55]: first, re-registration and medical tests; second, recruitment of small minority groups such as the Druze and Circassians; and third, the recruitment of small army units on a territorial basis. The IDF Chief of General Staff, Moshe Dayan, was not satisfied with this decision. It was clear that Dayan was against any Arab recruitment in the IDF but was in favor of the recruitment of the Druze, a group that was potentially large enough to meet the needs of the IDF [56]. Ultimately, this draft option was abandoned by Lavon due to a lack of political and military support to implement it [54]. It was suggested that such a plan could generate security threats if disloyal Arab citizens were given IDF weapons. When Ben-Gurion once again assumed the office of Prime Minister and Defense Minister in 1955, he preferred Lavon's option first to draft the Druze and Circassians.

Recruiting the Druze for the IDF was once again discussed in 1955. At that time, the Operations Directorate noted the difficulties associated with operating the Minorities Unit given the declining number of soldiers, which was due to the lack of new Druze volunteers and the transfer of some Druze soldiers to the Border Police. However, during these internal discussions, the non-military importance of the Minorities Unit was once again emphasized [57]:

"[ ... ] the purpose of this policy regarding the Druze is to keep the uniqueness of this ethnic group within the general Arab society in Israel and to prove, among other things, the possible full integration and solidarity of an Arab minority with the state. Other than the religious uniqueness and difference, any segregation of the Druze from the Arabs is artificial and intentional $[\ldots]$.

For this reason, an administrative effort was undertaken inside the IDF. As part of this effort, the Minorities Unit commander formulated a plan to recruit Druze men to the IDF reserve in order to prevent any possible discrimination in Druze society between the elderly who had volunteered for service and the youth who would be conscripted and those who neither had volunteered nor would be recruited due to their age [58]. The IDF's administrative effort concluded with two options to guarantee the continuation of the Minorities Unit. One solution was the maintenance of volunteer and employed soldiers. The second solution was to implement full conscription for Druze youth [59]. The IDF Deputy General Chief of Staff decided in October 1955 that to continue the Minorities Unit, the IDF would request full conscription for Druze youth. In November 1995, following this decision, 
the Minorities Unit began to officially prepare for the full conscription of Druze youth, which was expected to involve 60 soldiers in February 1956, 60 soldiers in May, and 30 soldiers in November [60].

However, to implement this new policy, approval from the Minister of Defense was needed. Prime Minister and Minister of Defense Ben-Gurion approved this policy-compulsory service for only the Druze among minorities-with one condition. Ben-Gurion asked for full confirmation from the Druze leaders and that written requests be directed to him [59]. Consequently, the headquarters of the Minorities Unit was ordered to convince all the Druze leaders in Israel to agree to the recruitment of Druze youth [61].

The efforts of the Minorities Unit officers were successful. They received confirmation and official requests from Druze leaders who were MKs or who were later chosen for one of the satellite parties affiliated with the MAPAI and subsequently became MKs. MK Salah Khanifes and former MK Jabr $\mathrm{Mu}$ 'adi, who was rewarded for his efforts by becoming an MK once again following the resignation of his colleague, were among the Druze leaders who submitted requests. Additionally, in January 1956, the mayor of Isfia, Labib Abu-Roken, also sent an official request [62]; Abu-Roken later became an MK.

By December 1955, requests were received from Druze leaders that urged the Israeli government to implement conscription for the Druze. In fact, the Israeli historiography regarding the "Covenant of Blood" between the Jews and the Druze was based on the recruitment of the Druze to the IDF at the request of the Druze leaders $[22,38,48,63]$. Supporting this claim are documents signed by six Druze leaders that were found in the archives [64]. As one of the Druze leaders wrote in a request for the conscription of Druze youth [65]:

"December 1955[ ... ] As a representative of the Druze religious council, I hereby join the request of my family members - Muadi - with respect to compulsory service [ ... ] Kamel Sliman Muadi"

A final request was intended to reflect the opinion of the most important religious leader among the Druze in Israel, Sheikh Amin Tarif. However, no evidence of a written request was found in the Israeli archives. Instead, there was a letter written by a member of the Tarif family and a Druze Qadi, Sheikh Salman Tarif, in support of conscription [66]. After receiving these requests and the alleged assistance of Sheikh Amin Tarif, Prime Minister and Minister of Defense Ben-Gurion approved the new policy of compulsory service for the Druze [67].

The preparations for the first cycle of recruitment in May 1956 began in February. Draft orders were sent to Druze youth; however, most refused to comply [68] based on a growing objection to the new policy, as will be explained further. The Israeli Police, the Military Police, the Military Government Administration, and the Israeli Security Agency were called in to enforce the first draft. These agencies met on a monthly basis to achieve the goal of implementing the policy. Some recruits were taken into custody, their families were punished, and their weapon permits were confiscated, and leaflets in Arabic on soldiers' rights were distributed, and meetings were held with the recruits and their families as well as with Druze leaders. Israeli officials claimed that if the new policy were followed in full, it would lead to a smooth process in the future. The efforts were successful, and by the planned recruitment date, most of the recruits had registered. As the Minorities Unit Commander noted [69]:

\section{"[ ... ] The recruits obeyed after they were legally 'encouraged' to do so by the police."}

Following implementation of compulsory service in the IDF, the Druze were granted some privileges: a one-year movement permit in areas under the administration of the military; the possibility of registering the nationality/religion of the Druze on Israeli identification cards; and the possibility of employing unemployed Druze in factories [53].

\subsection{The Compulsory Service of the Druze in the IDF-An Israeli Plan}

As discussed above, Israeli historiography describes the Druze's service in the IDF as an outcome of a Druze decision to integrate into Israeli society. This was implemented by the Israeli government at the request of the Druze leaders to explain the expansion of the compulsory conscription law 
to cover Druze youth in 1956. Thus, framing the "Covenant of Blood" between the Druze and the Jews established a common and shared destiny [42]. However, other scholars-mainly Arab scholars $[70,71]$ — claimed that the recruitment of the Druze to the IDF was part of a conspiracy by Israel that was enacted despite the opposition of most of the Druze leadership. Neither side, however, has provided substantial evidence to support their claims or endeavored to reach a definite conclusion. Thus, it is essential in this study to reveal the facts behind the decision regarding Druze service in the IDF and the reasons for implementing compulsory service in 1956.

As discussed above, compulsory service for the Druze in the IDF is the product of a well-implemented Israeli plan. The following points support this claim:

First, most of the Druze volunteers in the first years of the Minorities Unit were initially from Lebanon and Syria and not from Israeli villages [72]. These soldiers were nearly the only soldiers in the unit in the first half of the 1950s [73].

Second, the notion that the Druze requested compulsory service is contradicted by the disinclination of the Druze youth to comply with the draft. They were forced to comply only with the involvement of the military police and the police, and they did so later than planned. There were also hundreds of official documents sent from Druze youth, their families, and their lawyers asking the government to put an end to this policy [74].

Third, the archival documents reveal that there was a great objection from most of the official Druze leaders to the transition from recruitment to compulsory service [75]. In March 1957, a year after the first draft, a delegation of Druze leaders came to the Knesset to object to the decision. One of the leaders, Quftan Halabi, the mayor of Daliyat al-Karmel, said in the meeting [76]:

"[ . . ] We hereby declare that the Druze Knesset members do not represent the Druze society; on the contrary - they are traitors, and they have no connection to the Druze."

Fourth, the most critical piece of evidence from the archive documents indicates that the policy was the result of an official and well-organized plan led by the Prime Minister's advisor for Arab affairs and the Minorities Unit headquarters. As shown above, the Minorities Unit and the IDF had been discussing and preparing for compulsory service for the Druze since the early 1950s. Even the so-called Druze leaders' documents requesting the policy were elements of this plan: the documents were all from the same month, December 1955. Furthermore, all the archived documents relating to the Druze leaders' requests were written only in Hebrew, without an Arabic original, unlike all the other documents in the archive for that period. Additionally, there were no requests from the majority of the Druze community leaders in Israel during that period, such as the members of the Druze Religious Council (except one) and local leaders-Mukhtars (except one) and mayors (except one). As explained earlier, these documents were not the sent at the initiative of the Druze leaders; instead, they were a product of the pressure that the Minorities Unit placed on those leaders. The Deputy Northern Commander summarized this point [77]:

“... The Minorities Unit's efforts to achieve a Druze agreement to the compulsory service achieved as of today the opposite goal. [ . . . ] From Isfia the objection protests against the conscription efforts moved to Dalia and Beit-Jan. [ ... ] After multiple efforts, meetings, and agreements, some Druze agreed to sign such documents ..."

All of the above, in addition to other evidence, form the basis of the conclusion that gaining the support of the Druze leaders was part of a well-implemented plan and that only some of the new Druze leaders were part of that plan.

\section{Discussion}

This study followed an international-relations approach that distinguishes between negative peace-the reduction, prevention or absence of war and violence or the existence of 'structural violence' - and positive peace, which involves a sense of cooperation or 'the integration of human 
society' that emanates from the structure of a social system rather than from individual or group actors $[1,2$, and 3].

Our main contribution in this study is to offer the implementation of this international-relations approach to interstate relations. For our discussion, negative peace within a nation-state is the reduction, prevention or absence of violence between the majority and the ethnic minority achieved by controlling, reducing, preventing, or eliminating individual or violent group actions, not by resolving the structural violence. Similar to negative peace, the 'control paradigm' [12] is based on the premise that insecurity can be controlled through military force or containment, thus maintaining the status quo. In this case, positive peace requires that the ethnic minority feel a sense of cooperation with the nation-state, which can be achieved by integrating the ethnic minority into society and by eliminating structural violence within the society. The 'sustainable security' approach, similar to positive peace, prioritizes the resolution of the interconnected underlying drivers of insecurity and conflict and emphasizes preventive rather than reactive strategies.

Thus, this study concludes by affirming that those approaches are suitable also for the inter-state relations between the ethnic minority and a nation-state, in the case of Israel. Our case study confirms that policies implemented by the majority create inclusion or exclusion of ethnic minorities in a nation-state. Therefore, exploring issues regarding the security of a specific state or nation must involve gaining an understanding of its social system, including majority-minority relations, and implementing preventive strategies. This confirms the 'sustainable security' approach that prioritizes preventive strategies over reactive ones [11]. Consequently, an essential area of focus is the period during which a new state is established as the new entity defines its borders. This includes outlining not only physical land borders, which determine sovereignty and administration, but also the borders of society, which determine who is to be included in the new nation and who is excluded.

These conclusions are based on the case of the Israeli Druze and their integration into Israeli society, which contrasts with that of other Israeli Arabs who are largely segregated from other Israelis. In its first years as a nation-state, Israel implemented a 'control paradigm' over Arabs-who were considered as part of the enemy-on the premise that insecurity could be controlled through military force or containment, thus maintaining the status quo. This policy is consistent with the negative peace mentioned above. Simultaneously, Israel acted to change the status quo with the Druze, Circassians, Christians, and Bedouins, who were considered 'good' Arabs [31]. This approach was most successful with the Druze, as described in details in this study.

This study contributes further by showing that it was a formal Israeli policy aimed to achieve a positive peace and sustainable security with the Druze. It was achieved mainly through military service-first volunteer in 1948 and later compulsory in 1956-followed by a set of actions that distinguished them from other Arabs, as well as through additional policies that granted them rights in some areas more than were given to other minorities. Given the importance of national security in Israel due to ongoing threats, this study suggests that military service is the key to political and social integration in society. Consequently, the Israeli-Druze became the most integrated minority in Israeli society. This is in line with the findings of other scholarly work $[24,78]$ that also laid the responsibility on the government.

Recent evidence shows that there is still much to do to achieve full equality for the Druze in Israel. Other studies even suggest that the Druze experience the worst of both worlds: they serve in the army and some die in the line of duty as might any Jew, and they suffer the same discrimination that other non-Jews suffer [29,79]. Given our conclusion regarding the need for preventive strategies to achieve sustainable security and inner-societal positive peace that involves a sense of cooperation or integration of ethnic minorities into the nation-state, the state of Israel needs to aim at achieving as much equality as possible for the Druze and in order to eliminate any discrimination. This new policy may help even more strengthen the Druze's solidarity with the state.

Similarly, we suggest the negative peace that is present between the Muslim minority with the state of Israel and its Jewish majority, have had the potential to change in the early days of the 
country to positive peace, as the case with the Druze. This conclusion is in line with Geller [54], who suggested that a successful Arab draft-proposed by Lavon in 1954—could have positively improved the status of Arabs within Israel. However, the question remains whether the state of Israel and the Jewish-Israelis are willing to, and aiming at, achieving positive peace also with other fellow citizens-Muslim and Christian.

The recent developments in summer 2018 around the approval of the Nation-State bill [80], may, at first look, challenge the results of this study. The Nation-State bill, which was approved by the Knesset in July 2018, redefines Israel as the State of the Jewish People. It highlights its Jewish symbols and purpose to care for Jewish people while ignoring the Democratic character of Israel and ignoring its ethnic minorities. In response, many Israelis-Jewish and non-Jewish alike-protested the new legislation, however, the most high profile protests were held in August. One was a protest led by Druze and the other one led by other Israeli Arabs.

However, a careful examination re-affirms the conclusion that the positive peace with an ethnic minority in a nation-state is mainly a result of the majority and the state's actions. The Druze were the most vocal in their outcry to protest the new legislation, because the new bill, as they see it, does not include them as part of the "Israeli nation" [81]. Compared to other Arabs, the Druze felt more "Israelis", due to the positive peace that was achieved with them. Therefore, they felt the need to fight against the new legislation more than others who do not feel as such. Even in the protest itself, the Druze saw themselves as part of the Israeli collective and did not see themselves as part of the Arab collective. To add to this reaffirmation of this study's results, the use of Israeli symbols (i.e., flag and anthem) and list of high-tanked Jewish speakers who are veterans of security agencies, IDF, and the public sector-all present in the Druze-led protest and were absent in the other protest.

Moreover, the protest that was organized by the Druze gained much attention and support from the Jewish-Israelis and Hebrew media [82], conversely to the protest that was led by the other Arabs. Once again, affirmation of the positive peace with one group and negative peace with the others. All of these evidence act as another affirmation of the conclusions of this study. It reconfirms the status of positive peace with the Druze and the negative peace with the other Arabs in Israel, as a result of the Jewish majority and the state's decisions.

Funding: This research received no external funding.

Conflicts of Interest: The authors declare no conflicts of interest.

\section{References and Notes}

1. Gleditsch, N.P.; Nordkvelle, J.; Strand, H. Peace research-Just the study of war? J. Peace Res. 2014, 51, $145-158$. [CrossRef]

2. Galtung, J. Foreign policy opinion as a function of social position. J. Peace Res. 1964, 1, 206-230. [CrossRef]

3. Galtung, J. Violence, peace, and peace research. J. Peace Res. 1969, 6, 167-191. [CrossRef]

4. Winter DuNann, D.; Leighton, D. Structural violence: Introduction. In Peace, Conflict and Violence: Peace Psychology for the 21st Century; Prentice Hall: Upper Saddle River, NJ, USA, 2001; p. 99.

5. Rylko-Bauer, B.; Farmer, P. Structural violence, poverty, and social suffering. In The Oxford Handbook of the Social Science of Poverty; Oxford University Press: Oxford, UK, 2016; p. 47.

6. Independent Commission on Disarmament and Security Issues (Palme Commission). Common Security: A Blueprint for Survival; Simon \& Schuster: New York, NY, USA, 1982.

7. Westing, A.H. The environmental component of comprehensive security. Bull. Peace Propos. 1989, 20, $129-134$. [CrossRef]

8. Buzan, B.; Wæver, O.; Wæver, O.; De Wilde, J. Security: A New Framework for Analysis; Lynne Rienner Publishers: Boulder, CO, USA, 1998.

9. U.N. Development Program (UNDP). Human Development Report 1994; Oxford University Press: Oxford, UK, 1994.

10. Human Security Centre. Human Security Report 2005: War and Peace in the 21st Century; Oxford University Press for the Human Security Centre, University of British Columbia: New York, NY, USA, 2005. 
11. Zala, B. The Strategic Dimensions of Water: From National Security to Sustainable Security. In Water Security; Routledge: Abingdon-on-Thames, UK, 2013; pp. 291-306.

12. Khagram, S.; Clark, W.; Raad, D.F. From the environment and human security to sustainable security and development. J. Hum. Dev. 2003, 4, 289-313. [CrossRef]

13. Jenne, E.K.; Saideman, S.M.; Lowe, W. Separatism as a bargaining posture: The role of leverage in minority radicalization. J. Peace Res. 2007, 44, 539-558. [CrossRef]

14. The Law of Return. 1950. Available online: https://www.knesset.gov.il/laws/special/heb/chok_hashvut. htmURL (accessed on 7 March 2016). (In Hebrew)

15. Jamal, A. On the morality of Arab collective rights in Israel. Philosophy 2003, 11, 65-88.

16. Packer, J.; Kristian, M. The Protection of Ethnic and Linguistic Minorities in Europe; Institute for Human Rights, Åbo Akademi University: Turku, Finland, 1993.

17. Halabi, R. Invention of a nation: The Druze in Israel. J. Asian Afr. Stud. 2014, 49, 267-281. [CrossRef]

18. Rekhess, E. The evolvement of an Arab-Palestinian national minority in Israel. Isr. Stud. 2007, 1, 1-28. [CrossRef]

19. Smooha, S. Still Playing by the Rules: Index of Arab-Jewish Relations in Israel 2012: Findings and Conclusions; University of Haifa: Haifa, Israel, 2013.

20. Amara, M.; Schnell, I. Identity Repertoires among Arabs in Israel. J. Ethn. Migr. Stud. 2004, 30, $175-193$. [CrossRef]

21. Akirav, O. Catch-22: Arab Members of the Israeli Parliament. Representation 2014, 50, 485-508. [CrossRef]

22. Frisch, H. Israel's Security and Its Arab Citizens; Cambridge University Press: Cambridge, UK, 2011.

23. Peleg, I.; Waxman, D. Israel's Palestinians: The Conflict Within; Cambridge University Press: Cambridge, UK, 2011.

24. Zaidise, E.; Canetti-Nisim, D.; Pedahzur, A. Politics of God or politics of man? The role of religion and deprivation in predicting support for political violence in Israel. Political Stud. 2007, 55, 499-521. [CrossRef]

25. Zeedan, R.; Vigoda-Gadot, E.; Ben-Artzi, Y. Causes of (and solutions for?) financial crises in local governments: Insights from local Arab authorities In Israel. Adm. Soc. 2017, 49, 1065-1083. [CrossRef]

26. For more details on the establishment of the Committee of Druze and Circassian Mayors, see Al-A'mama, Vol. 82, 2007. Available online: http:/ / www.al-amama.com/index.php?option=com_content\&task=view\& $\mathrm{id}=645$ (accessed on 20 May 2016). (In Arabic)

27. Atashi, Z. The Druze in Israel and the Question of Compulsory Military Service; Jerusalem Letter; Jerusalem Center for Public Affairs: Jerusalem, Israel, 2001; p. 464.

28. Yiftachel, O.; Segal, M.D. Jews and Druze in Israel: State control and ethnic resistance. Ethn. Racial Stud. 1998, 21, 476-506. [CrossRef]

29. Hamdy, I.A. The Druze in Israel: A less persecuted minority? Contemp. Arab Aff. 2008, 1, 407-416. [CrossRef]

30. Bowen, GA. Document analysis as a qualitative research method. Qual. Res. J. 2009, 9, 27-40. [CrossRef]

31. Cohen, H. Good Arabs: The Israeli Security Agencies and the Israeli Arabs 1948-1967; University of California Press: Berkeley, CA, USA, 2011.

32. Eyal, G. The discursive origins of Israeli separatism: The case of the Arab village. Theory Soc. 1996, 25, 389-429. [CrossRef]

33. Census of Population and Housing; Central Bureau of Statistics: Jerusalem, Israel, 1956. (In Hebrew)

34. Special Census Edition of the Newly Occupied Territories in 1967; Central Bureau of Statistics: Jerusalem, Israel. (In Hebrew)

35. Shtendal, U. Ha-Miutim [Minorities]; Ministry of Education: Jerusalem, Israel, 1972. (In Hebrew)

36. Cohen, E.; Gronaw, H. The Arab Census in Israel; Center for Arab and Afro-Asian studies, Hebrew University of Jerusalem: Jerusalem, Israel, 1972. (In Hebrew)

37. Parsons, L. The Druze between Palestine and Israel, 1947-49; Macmillan: Stuttgart, Germany, 2000.

38. Epstein, E. The Druzes of Palestine. J. R. Cent. Asian Soc. 1942, 29, 52-63. [CrossRef]

39. Falah, S. A history of the Druze settlements in Palestine during the Ottoman period. In Studies on Palestine during the Ottoman Period; Ma'oz, M., Ed.; Magnes Press: Jerusalem, Israel, 1975. (In Hebrew)

40. Palestine. The Palestine Order in Council. 1922. The Question of Palestine. Available online: https:/ / unispal. un.org/DPA/DPR/unispal.nsf/0/C7AAE196F41AA055052565F50054E656 (accessed on 1 June 2016).

41. Law of Rabbinical Courts Jurisdiction (Marriage and Divorce). 1953. Available online: https://www.knesset. gov.il/review/data/heb/law/kns2_rabbiniccourts.pdf (accessed on 21 September 2016). (In Hebrew) 
42. Frisch, H. The Druze minority in the Israeli military: Traditionalizing an ethnic policing role. Armed Forces Soc. 1993, 20, 51-67. [CrossRef]

43. Edelman, M. The Druze Courts in the Political-System of Israel. Middle East Rev. 1987, 19, 54-61.

44. Landau, J.M. The Arabs in Israel: A Political Study; Routledge: Abingdon-on-Thames, UK, 2015.

45. Firro, K.M. Reshaping Druze Particularism in Israel. J. Palest. Stud. 2001, 30, 40-53. [CrossRef]

46. Population Registration Act, 1965. The Knesset, 2016. Available online: https://www.knesset.gov.il (accessed on 27 May 2016). (In Hebrew)

47. Oppenheimer, J. The Druze in Israel, as Arabs and non-Arabs: An essay on the manipulation of categories of identity in a non-civil state. Camb. Anthropol. 1978, 2, 23-44; The inclusion of nationality/religion on the Israeli identification card was eliminated in 2002 following a decision by the Supreme Court in 2000. However, the records of the nationality/religion of each Israeli citizen are still maintained as part of personal records in the database of the Ministry of the Interior.

48. Ben-Dor, G. The military in the politics of integration and innovation: The case of the Druze minority in Israel. Asian Afr. Stud. 1973, 9, 339-369.

49. Kaufman, I. Ethnic affirmation or ethnic manipulation: The case of the Druze in Israel. Natl Ethn. Politics 2004, 9, 53-82. [CrossRef]

50. Zeedan, R. The History of the Minorities Unit in the IDF from 1948 to 1956; Battalion of Arab; Modan Publishing, in cooperation with Maarachot: Ben Shemen, Israel, 1950. (In Hebrew)

51. Gelber, Y. Druze and Jews in the War of 1948. Middle Eastern Stud. 1995, 31, 229-252. [CrossRef]

52. Major General Shlomo Shamir's letter to all IDF branches announcing the decision to establish the Minorities Unit, 24 August 1948, 339-2289/1950, IDFA.

53. Avivi, S. Tas Nehushit [Copper Plate: Israeli Policy towards the Druze, 1948-1967]; Yad Ben-Zvi: Jerusalem, Israel, 2007. (In Hebrew)

54. Geller, R.S. Defense Minister Pinhas Lavon and the Arab Draft That Never Was. Isr. Stud. 2014, 19, 1-23. [CrossRef]

55. An internal memo by the Minister of Defense, 7 September 1954, 46-636/1956, IDFA.

56. Based on a personal letter from the IDF Chief of General Staff, Moshe Dayan, to the Minister of Defense, 13 September 1954, 46-636/1956, IDFA.

57. Taken from a document: "The problems in recruiting the Druze to the IDF" (No clear name of the writer), 23 January 1972, 73-18/1974, IDFA.

58. Letter from the Minorities Unit commander to the IDF Deputy General Chief of Staff, 18 November 1955, 46-222/1957, IDFA.

59. Letter from Issar Halamish, the Minorities Unit Deputy Commander to the Operations Directorate, 10 October 1962, 752-72/1970, IDFA.

60. Letter from Tzvia Yakob, the Minorities Unit Commander, to Company 300, 23 November 1955, 5-222/1957, IDFA.

61. Letter from the Staff Department Commander to the Minorities Unit Commander, 27 November 1955, 67-637/1956, IDFA.

62. Letter from the mayor of Isfia, Labib Abu-Roken, to the Prime Minister and Minister of Defense, 3 January 1956, 76-776/1958, IDFA.

63. Azrieli, Y.; Abu-Roken, J. Fraternity Tested: Druze in the Battles of the Yishuv and the State; World Zionist Organization: Jerusalem, Israel, 1989.

64. Letter from A'li Mulhem Moa'di: A document from Major-General Tziva Yakoob, the Minorities Unit commander, to the Prime Minister's advisor for Arab affairs, 27 December 1955; Tawfeek Yosef, the chair of the Jat council, and Faiez Salah Yosef, the Mukhtar of Jat, to the commander of the Minorities Unit, not dated (previous and next documents are dated to December 1955); Kamel Suliman Moa'di, member of the Druze Religious Council, to the commander of the Minorities Unit, 24 December 1955; Farhan Tareef to the Defense Minister, 18 December 1955; Saleh Khnefes to the Defense Minister, not dated (previous and next documents are dated to December 1955). All records from the, 5-222/1957, IDFA.

65. Letter from Kamel Suliman Moa'di, member of the Druze Religious Council, to the commander of the Minorities Unit, 24 December 1955, 5-222/1957, IDFA. 
66. Letter from Sheikh Salman Tarif to the Military Governor of the Galilee, Michael, 22 January 1956, 752-772/1970, IDFA; and a letter from Sheikh Salman Tarif to the Prime Minister and Minister of Defense, 22 January 1956, 160-642/1956, IDFA. Sheikh Salman Tarif's son wrote these two letters on behalf of his father.

67. Letter from Ben-Yosef to Mr. E. A'mir, the Chief of Manpower Directorate, 23 January 1956, 279-220/1974, IDFA. In this letter, Ben-Yosef states that the decision was made based on the support of the two Druze MKs and the support of the religious leader of the Druze, Sheikh Amin Tarif.

68. Letter from A. Niv, Department of Recruitment Commander, to E. A'mir, Directorate of Manpower Chief in the Ministry of Defense, 26 February 1956, 76-776/1958, IDFA.

69. Letter from the commander of the Minorities Unit to the Manpower Directorate, 9 April 1956, 29-299/1958, IDFA.

70. Firro, K. The Druzes in the Jewish State: A Brief History; Brill: Leiden, The Netherlands, 1999.

71. Ghurayzi, W. Mu'anat al-Muwahhidin al-Duruz fì al-ard al-Muhtallah [The Suffering of the Druze in the Occupied Terretories]; Dar al-Kutab: Beirut, Lebanon, 1984. (In Arabic)

72. Letter from the commander of the Minorities Unit to the Food Inspector, 19 August 1948, C-20/1318, ISA.

73. Letter from the commander of the Minorities Unit to the Department of Military Governance, 23 February 1955, 1-222/1957, IDFA.

74. For such examples, see Zeedan, R. The History of the Minorities Unit in the IDF from 1948 to 1956; Battalion of Arab, Ben Shemen, Israel: Modan Publishing, in cooperation with Maarachot. (In Hebrew pp. 181-187 and pp. 233 (comment 519)).

75. For example: A letter from a group of family leaders from Shefar'am, 19 March 1956, 76-776/1958, IDFA; a letter from a group of family leaders from Yarka, 16 February 1956, 76-776/1958, IDFA; a letter from a group of family leaders from Isfia, 20 March 1956, 76-776/1958, IDFA.

76. Protocol of the Knesset Public Petitions Committee, 5 March 1957, 752-772/1970, IDFA.

77. Letter from the Deputy Northern Commander to the Operations Directorate, 26 January 1956, 752-772/1970, IDFA.

78. Batta, A. Patterns of Ethnic Marginalization and Inclusion in New States. Ethnopolitics 2017, 16, 471-487. [CrossRef]

79. Aboultaif, E.W. Druze Politics in Israel: Challenging the Myth of "Druze-Zionist Covenant". J. Muslim Minor. Aff. 2015, 35, 533-555. [CrossRef]

80. Basic Law: Israel-The Nation-State of the Jewish People (p/1989/20). Available online: www.knesset.gov.il (accessed on 9 January 2019).

81. A personal encounter with protesters during the protest-August 4th, 2018.

82. Rasgon, Adam. Druze revolt: Why a tiny, loyal community is so infuriated by nation-state law. The Times of Israel, 8 August 2018. 